\title{
The Implementation Genre-Based Approach in Teaching Reading at Senior High School
}

\author{
Wiwiek Angraini ${ }^{*}$ and Yenni Rozimela ${ }^{2}$ \\ I*Universitas Negeri Padang, Padang, Indonesia, $ه$ (email)wiwiekangraini92@gmail.com \\ ${ }^{2}$ Universitas Negeri Padang, Padang, Indonesia, $ه$ (email) yennirozi@gmail.com
}

\begin{abstract}
This article was written to describe one of studies the application of Genre-Based Approach (GBA) in teaching reading at senior high school. The objective of this research is to describe the implementation of Genre-Based Approach (GBA) in teaching English. This research is descriptive study using observation and interviews as research instrument. The data analysis followed the steps such as data managing, reading and memoing, description, classifying and interpreting. The result of data analysis raised three point to be discussed; the difficulties faced by the teachers in implemented GBA in process of teaching English, and this research shows that GBA has good influence in development teachers and students' competency. This research implies that the teachers need to improve their professional competence, their knowledge and skills so that they will be able to create conducive atmosphere in the class. The research finding of this study indicates that the implementation of GBA in teaching English in senior high school gives good contribution to the improvement of the students' language proficiency. Therefore, it is recommended that the teachers should have to apply the four steps of the curriculum cycle in the teaching of genres.
\end{abstract}

Keywords: Implementation, Genre-Based Approach (GBA)

\section{INTRODUCTION}

Indonesia curriculum has undergone several changes in the past three decades, starting from curriculum 1994, School Based Curriculum (CBC in 2004), KTSP (2008), and Curriculum 2013 (2013). Curriculum 2013 encourages students to be able to find out relevant information, make observations or experiments, in order to find relationships that are relevant to the approach that will be used. In accordance with Government Regulation No 68, 69 and 70 of 2013 which states that the Curriculum 2013 aims to prepare teachers and students to have he good ability to live as individuals and citizens and have innovative, faithful, productive, creative, affective thinking and able to contribute to social life, their nation, state, and world civilization for the future era. It is clear that the 2013 Curriculum requires students to be able to contribute to society with the abilities they obtain from the teaching and learning process.

Permendikbud No. 54, 2013 which is explained that students need to have adequate knowledge about various text genres and skills to create various genres of text. To arrive at this goal, the teacher can explain to students that the main point in understanding the concept of text genre is knowing social goals of each genre and similarities in structure.

The next objective of the Minister of Education and Culture is expected students able to build communication in accordance with the context, have knowledge adequate concept of the use of language and literature in a variety of ways text genre, and have skills in using language and literature verbally and in writing for activities of thinking, acting, expressing, and be creative. The purpose of the explanation is at the next stage of the students expected to be able to convey or sharpen speaking and feeling skills believed himself to be related to the genre of text he had made.

To fullfill the competence required in 2013 curriculum, teachers are give freedom to choose the approaches suggested by the curriculum. There are some approches that English teachers could use in learning and teaching process, such as Scientific Approach, ProblemBased Learning, Project-Based Learning, Contextual Teaching and Learning, Genre-based Approach, ect. Each approach begins with an effort to attract the attention of the students and motivate students in learning process and conclude with closing stage of the lesson, which include activities to summarize the main points of learning carry out by the students with teacher guidance.

Furthermore, as the one of skill in leaning English, reading is the important that teachers and students have to comprehend, especially in teaching English in senior high school. Students could improve their language and enhance the knowledge by reading. Many experts define reading in different ways. According to Ahuja (2001), reading is an exercise dominated by the eyes and brain. Both of eyes and brain have to work out the message with significantly. It requires the students to read not only the content but also the meaning of the text. Teacher as the facilitator and mediator have to give more 
understanding to students about the material that will be taught the classroom.

In Padangpanjang there are two favorite schools. Senior High School Number 1 and Senior High School number 2 as the favorite schools in Padangpanjang are located on the centre of Padangpanjang. The researcher interviewed some of the students in both schools, the English teachers teach with pleasant and enjoyable way of teaching. When the researcher interviewed the students about the reading lesson, they like the English teachers taught them using activities which able to evade them from the boredom and the students do not feel bored with the teacher motivation, and they could get the high score based on the MCC. From the interviewed the teachers, it indication that the teacher using the GBA in their teaching and learning procces.

GBA is not a new approach; it has been introduced and enforced in Indonesia since School-Based Curriculum and still in use until the 2013 Curriculum. It seems Genre-Based Approach is considered one of appropriate teaching approach to be used in the learning process that focuses on understanding and producing text. Additionally, Rodgers (2001) states that in the new millennium era, Genre- Based Appoarch will be a major trend in learning English (ELT).

GBA is an approach that is implemented by English teachers in teaching process of all the skills in English. Moreover, in implementing GBA, teachers need to conduct learning and teaching process based on steps of GBA and known the cyles. The model of Genre-Based Approach has four stages. BKOF (Building Knowledge of the Field), MOT (Modeling of the Text), JCOT (Joint Construction of the Text), and ICOT (Independent Construction of the Text) can be accommodated in the Scientific Approach. This approach emphasizes the students active in learning and teaching process.

Therefore, due to this reason the researcher carries out this research to find the teachers implement GBA in teaching reading which result in good learning outcome and their likeness toward English. The researcher also want to know how the english teacher implement the GBA in their classroom based on the previous interviewed that students explaned they like how the teachers teach them and get the high score in English study that indicated the teachers use GBA in learning and teaching process.

The researcher takes tenth grade students as the object of the research. It is because they are still new students who learn about the reading skill using genrebased approach method of senior high school, and they have good preparation in understanding about the material.

Based on some phenomena above, this research aims at finding out and observing what have been done by the teachers in the classroom, especially in teaching English reading text in Curriculum 2013. This research focuses on the problem on the implementation GBA in teaching English reading texts in senior high school in Padangpanjang.

\section{METHOD}

This reseach is qualitative study that will investigate implementation GBA in teaching reading in senior high school. This design is deemed suitable because descriptive will allow the researcher to describe, analyze, categorize and interpret the data in order to reveal the answer of the subject study.

Based on the explanation above, the purpose of this research is to describe running situation and implementation based on the empirical facts or studies in the field. This research deals with Implementation of Genre-Based Approach in teaching reading text in Senior High Schools in Padang Panjang.

The setting is at senior high schools in Padangpanjang. This school is located in the centre of this city. The researcher will conduct the research in SMAN 1 and SMAN 2 in grade $X$. The schools are selected due to its location which easy to reach and close to the city center. The researcher will conduct the research in the second semester of the academic year 2019/2020 on Januari 2020. Based on the preliminary observations looking for schools that implemented GBA, both of two schools still using GBA in teaching English, include in teaching reading skill. This research will be carried out into two schools; SMAN 1 and SMAN 2 Padangpanjang. The participants consist of two English teachers who are observed their teaching reading in English. There are one English teacher in each schools as the participants. The participants are chose that have deep knowledge and experience in implementing GBA in teaching reading skill.

There are two instruments used in collect the data, namely; classroom observation and interview. In classroom observation, researcher will observes the English teacher as informant in learning and teaching process, at least three times from each teacher to see the technique used by the teachers teachers in teaching reading text based on GBA. Observation sheet consists of components which involves the process of learning and teaching in GBA. The researcher will check the observation sheet when the behavior appear. The expected behaviors that appear will be give by tick in coloum 'yes' or 'no'. Observation guide will be validated by a validator. The indicators will present in appendix.

The second instrument is interview. The selected English teachers in both schools will be interviewed to find out they implement Genre-Based Approach, the problem they face and also the solution they used to overcome the problem. Moreover, the interview will be held in an informal situation and a relaxed atmosphere to make the informant could share anything about the implementation GBA. The questions of interview are not structured and observation checklist can be used as the guide line of the interview.

Techniques of data collection employed are observation and interview. Observation will be conducted to obtain information about how the process of teaching and learning goes when teacher implement Genre-Based Approach. In doing the observation, the researcher will not get involved in classroom observation. The observaton 
will be conducted at least two kinds of texts for each English teachers who taugh at the first grade. It is expected that with two twxta can find the tendency of the implementation GBA in reading skill.

Observation focused on the process of learning and teaching activity using GBA. In observation, researcher goes behind the process of learning and teaching of English from the beginning to the end of activities. Thus, teacher and students' activities are examined deeply. Observation is to get the deeper understandings and information to provides a knowledge of the contexts which the event occur, and it enables for researcher to see many things that the participants are not aware of, or that they are reluctant to discuss.

Researcher will conduct the interview as the technique to complete and make sure the data about Implemention GBA from the observation. Researcher interview the English teacher related to their implementation of GBA mainly about problem and causes problems they encountered as well as the problem solving. The interview is in informal situation and unstructured interview with relaxing environment. The subject of the interview will be anonym unless otherwise negotiated and agreed, and it will be recorded to ease the researcher in collecting the data

Thereafter,an interview used in a direct face-toface attempt to obtain the validity and reliability measurement in form of verbal responses from one or more respondents. It is will be a conversation in which the roles of the interviewer and the respondent change continually based on the situation. The interview will be done in the teacher room after the observation. The interviews are focused on interviewing the English teacher. In this study, the researcher use in-depth interviewing research type to investigate deeply the interviewees' last experience, expectation, about teaching of English using genre based approach. In-depth interviewing is the technique used in this research. In the simple way of thinking, in-depth interviewing means something in the heart relates to the past, at present, even in the future can be searched deeply. On the other way round at the very heart of human ability is that to symbolize their experiences through language. The aim is to get information directly about the implementation of the use GBA in process of learning and teaching of English.

Researcher will analyze the data using the technique developed by Gay and Airasian (2000) which consist of five steps as follows:

1. Data managing.

In analyzing the data, the researcher will manage the data that involve creating and organizing data of collection during teaching reading based on GBA. The purpose is to organize, to check for complete and to start analyzing the data collected by using observation checklist and interview guide. The data from the observation and interview will be collected and organized in good arrangement based on each teacher observation and interview schedule. Then the researcher also checks the completeness of the observation and the interview of each English teacher as the participant in the research. After ensuring the amount of data needed, researcher move to the next steps that is reading the data.

2. Reading and memoing

The researcher read the data from observation and interview that are already prepared. The aim of this step is having a record of thoughts and sense of data. In the end, the researcher will be able to record the common thread or the repitition of the activities of English teachers in implementing Genre-Based Approach as well as the problems and the solutions.

3. Description

The research will describe all of the data that are collected during observation checklist and interview. The researcher tries to describe by narrative way, the problems and solution that English teacher encounters in Implemention GBA that include process of teacher in implementing GBA and all activities involves in teaching process.

4. Classifying.

The data during teaching learning process will be classified into smaller units. Classifying data is needed in order to categorize based on itstype and analyze them partly based on each indicators. The classification will focus on teachers teaching process in Implemention the GBA and the problem that activities that often and rarely appear in Implemention GBA

5. Interpreting.

Data gathered will be interpreted in order to get a better result. Interpreting data is based on what happen during teaching learning process. In addition, analyzing and interpreting data are controled so that the description will focus on research.

\section{RESULTS AND DISCUSSION}

The data that will be present based on the literature reviewed. There are some data from the literature review based on some researchers. First, Destri (2015) found that in her research with entitle "The Implementation of Genre Based Approach in Teaching Reading: A case study at SMPN 17 Pekanbbaru”, in some stages the teacher does not carry out activities that shout be in that stage, and the other teachers have performed the stage well but tehre is no reading activities. She also found some difficulties that face by english teacher in using GBA. In conducting BKOF phase, all English teachers were more emphasized on doing the steps of preparing students to get into the topic and sharing experience. Meanwhile, the other steps such as building cultural context and vocabulary were not done ideally. In building cultural context, all English teachers did not apply this step. In interview, they said that they did not know how to apply this step. In MOT phase, all English teachers applied all steps in this phase. However, most teachers did 
not apply the steps well. The teachers had difficulty to make students be able to analyzing the generic structure, the social function, and linguistic features of text. It was because the students could not comprehend about the content of the text and the teachers did not give direct experience to the students in comprehended of the text. In JCOT phase, the difficulties were related to the students' less participation. The students sometimes did not want to participate actively in their group because they relied on the other students to finish the task. Not all the students were motivated to do their group work. If they were out of control so, only some students actively engaged in the group work. In conducting ICOT phase, most teachers were forced to instruct the students to do it at home or continued for the next meeting. In the interview, all English teachers had difficulty which was caused by the limited time. It made them unable to invite the students to present their individual work.

Efa and Yosnino (2015) research the implementation genre based approach in two kind of text; narrative text and report text. From several teachers studied, each teacher did a different way of explaining the text, some of them explained the concept at the beginning and then explain the text, and vice versa. The result of this reasearch in Implementation of GBA of narrative and report texts in teaching reading is in the first aspect of the implementation GBA of narrative and report texts in teaching reading the teachers had to teach all the components of narrative and report texts, such as social function to make the students comprehend the text a lot and the students know the writer's purposes. In the second aspect, the teachers had to explain the aspects of generic structure of narrative and report texts in regulary that students could comprehend and found the main idea and general and specific information in the text easily. In the third aspect, the teachers had to explain the aspects of lexicogrammatical features to make the students know the characteristic of each genre. In the fourth aspect, the teachers had to have classroom organization, physical facility and continuity but also it was also to create and maintain the classroom situation and condition. But it was not done by teachers totally. Problems faced by the English teachers in implementing GBA in teaching reading are vocabulary. The first factor is the instructional material, the teachers had to develop the syllabus to use it based on students' potencies and local characteristic. But none of them do them. The second is the instructional media, the teachers should use the traditional and modern media but only two of them used them. The third factor is the instructional activity; the teachers had to have procedures in implementing the GBA in teaching reading, but none of them do it. The fourth factor is the classroom management the teacher should have the good condition of classroom and variation in learning-teaching process, but some of the criteria had done already by the English teachers.

Third, Tartila (2013) with entitle "The Implementation of Genre Based Approach in English Teaching at Islamic Senior High School Model (MAN Model) Jambi". She found that In conducting building knowledge of the field, most teachers emphasized on doing the step preparing students to get into the topic and sharing experience only. Meanwhile, the other steps were only done at a glance. In giving model of the text to students, almost all the teaching steps were applied by the teachers. However, those steps were still not ideally applied. In giving example of the text, the teachers were really dependent on the use of model texts available in students' work sheet, the students were also demanded to do the exercise beneath the text as the way some of teachers will discuss the contents consist of the text. When teachers conducted the stages named JCOT all teachers could do well except asking another group of students to respond to the text presented. It was because this step was only done by one teacher. Leading the students to respond to their friends' work give several advantages. In conducting the stage of ICOT, all teachers were forced to instruct the students to do it at home. Besides, none of them guide students to check their own task.this reseach also found the problems faced by the teachers in implementing GBA such as teachers found difficult to conduct all the steps teaching totally because students sometimes did not understand about their teaching because they had lack vocabulary. In giving model of the text studied teachers had difficulty to make students able to analyze the linguistic features, the generic structures and social functions of the text. It was because the students could not understand about the content of text easily. The comprehension of text really determines students' ability to know the certain features of the text. In the stage JCOT, it seems that teachers did not encounter too significant problems. The problems were related to the students' less participation. Students sometimes did not want to participate actively in the instructional process. The Problem Solving Conducted by the English Teachers in Implementing GBA, Most of the teachers solved the problems by doing bilingual teaching in which teacher used English first then translated into Indonesian. Other ways conducted by teachers were by asking the students in reading more texts by themselves at home or whereever their feel comfortable. Sometimes, teachers instructed the students to underline the difficult words contained in the text, and then find the meaning by consulting to the dictionary, and finally the students were obliged to memorize the words or develop the words into sentences.

\section{CONCLUSION}

This research concluded that GBA gives good impact to the development of teachers' and students' competency. This research suggest that teachers should improve their professional competence, their knowledge and skills. Moreover, the implementation of GBA also gives good contribution to the improvement of the students' language proficiency. This research recommends teachers to apply the four steps of the curriculum cycle in the teaching of genres. 


\section{REFERENCES}

[1] Atmazaki. 2013. Implementasi Kurikulum 2013 Mata Pelajaran Bahasa Indonesia: Pola Fikir, Pendekatan Ilmiah, Teks (Genre), dan Pendekatan Otentik. ISBN: 978-602-17017-2-0 ISLA 2. FBS Universitas Negri Padang.

[2] Berg, Bruce L. 2001. Qualitative Research Method for Social Sciences. Boston: Allyn and Bacon

[3] Cunningham, A. E. and Stanovich, K. E. 2001. What Reading Does for the Mind. Journal of Direct Instruction. Summer 2001 (online). http://www.csun.edu/krowlands/Content/Academi c_Resources/Reading/UsefulArticles/Cunningham-What-Reading-Does-forthe-Mind.pdf (accessed on March $26^{\text {th }} 2015$ ).

[4] Derewianka, B. 1990. Exploring How Texts Work. Autralia: Autralian Print Group

[5] Derewianka. B. 2003. Trends and Issue in GenreBased Approaches. RELC 34.2 (2003) 133-154. ISSN 0033-6882.

[6] Wahyu, Desri N. 2015. The Implementation of Genre-Based Approach on Teaching Reading: A case study at SMPN 17 Pekanbaru. Volume 1 No 1, Maret 2015. Journa; English Language Teaching (ELT)

[7] Dirgeyasa. 2016. Genre-Based Approach: What and How to Teach and to Learn Writing. Universitas Negeri Medan, Indonesia.

[8] Silvia, Efa. Yonsisno. 2015. The Implementation of Genre-Based Approach in Teaching Reading at Grade XI of SMAN 2 Sungai Penuh. Volume 17, No 2, Hal 18-24. ISSN: 0852-8349

[9] Ermawati. The Implementation of Genre-Based Approach in Teaching English Reading Texts at Public Senior High Schools in Bukittinggi. UNP. Unpublished.

[10] Fatihatul. Hervinda N, 2017. The Implementation of Genre-Based Approach in Teaching Reading Skill at the Tenth Grade Students of MAN Karanganyar in the Academic Year 2016/2017. The state islamic institute of surakarta.

[11] Fauziati, Endang. 2009. Introduction to Methods and Approaches in Second or Foreign Language Teaching. Surakarta: Era Pustaka Utama.

[12]Feez, S. dan H. Joyce. 2002. Text-Based Syllabus Design. Sydney: NCELTR, Macquarie University.

[13] Gay. Airasian. 2000. Educational Research: Competencies for Analysis and Application. Paper Saddle River, Ney Jersey: Merrill Publishing Company

[14] Gay and Airasian. 2012. Educational Research. Tenth Edition. Pearson. Boston

[15] Hyland. Ken. 2007. Genre and Second Language Writing Framing the Issue. Reserach Gate. University of East Anglia.
[16] Mariane Celce-Murcia and Elite Olsthain. 2000. Discourse and Context in Language Teaching. United Kingdom: Cambridge University Press.

[17] Nunan d. (1998). Second Language Teaching and Learning. Boston Heinle \& Heinle

[18] Paltidge, B. 1996. Genre, Text Type and Language Learning Classroom. ELT journal number 50 volume 3

[19] Rochmadi. Wahyu. 2013. Pendalaman Kurikulum. Kementerian Riset, Teknologi dan Pendidikan Tinggi Universitas Negeri Malang Lembaga Pengembangan Pendidikan dan Pengajaran P4l 2016.

[20] Shafa . 2014. Karakteristik Proses Pembelajaran Kurikulum 2013. Samarinda

[21] Swales, M. John. 1990. Genre analysis: English in Academic and Research Settings. Cambridge: Cambridge University Press.

[22] Tatila. A, Yasin. Yenni, R. 2013. The Implementation of Genre-Based Approach in English Teaching at Islamic Senior High School Model (MAN Model) Jambi. Volume 1 No 3, November 2013. Journal English Language Teaching (ELT)

[23] Tuan, Luu Trong. 2011. Teaching Writing through Genre-Based Approach. Theory and Practice in Language Studies. Theory and Practice in Language Studies volume 1 number 11

[24] Yosmi. Getreda O, 2008. The Implementation of Genre-Based Approach in the Teaching of English at SMAN 2 Surakarta (A Naturalistic Study in 2007). Sebelas Maret University. 